\begin{tabular}{c} 
Volume and Issues Obtainable at Center for Sustainability Research and Consultancy \\
Journal of Accounting and Finance in Emerging Economies \\
ISSN: 2519-0318 ISSN (E) 2518-8488 \\
Volume 1: Issue 2December 2015 \\
CSRC \\
Journal homepage: www.publishing.globalcsrc.org/jafee \\
\hline
\end{tabular}

\title{
Detecting Earning Management: Deferred Taxes Vs Accruals: A Pakistani Perspective
}

\author{
${ }^{1}$ S. M. Aamir Shah, ${ }^{2}$ Imran Shanwari \\ ${ }^{1}$ Associate Professor, Allama Iqbal Open University, Islamabad Pakistan.dramirshah@aiou.edu.pk \\ ${ }^{2}$ Research Scholar, Mohammad Ali Jinnah University, Islamabad Pakistan.
}

\begin{tabular}{l}
\hline ARTICLEDETAILS \\
\hline History \\
Revised format Nov 2015 \\
AvailableOnline Dec 2015
\end{tabular}

Keywords

Earning Management

Deferred Taxes

Accruals

Karachi Stock Exchange

JEL Classification:

M12, M19, H25, H29

\begin{abstract}
Objective: Earning Management has been one of the major areas of accounting research which has received a great attention in the past and also quite recently. Detecting earning management has always been one of the major areas of concern for the researchers. Earnings Management is pervasive. There are a number of models available to Detect and measure the earnings management activity.

Methodology: The accrual models are the most used models to proxy the discretionary accruals and the earnings management. The effectiveness of the accrual models is somewhat skeptical at times when researchers found some inconsistencies in results while using the accrual models. The researchers are still finding some better and effective model that can be used to better measure and capture the earnings management activity. The focus of this study is to find out as to whether a deferred tax as compared to accrual models is more useful in measuring or detecting the earnings management in Pakistani perspective. The study is based on the Pakistani companies listed on the Karachi Stock Exchange (KSE). This study is expected to be an addition to the existing research as to whether the models used for detecting earnings management through deferred taxes by Philips et al (2003) are also applicable to Pakistani Scenario which is a developing country. The study used Probit Regression Model with pooled cross sectional data to measure the usefulness of both; accruals and deferred taxes (the proxies) used as better measure for Earningsmanagement.

Results: The results of the study are inconsistent with the Philips et al. (2003) study. Based on this study it is concluded that deferred tax is not incrementally useful along with the other accrual measure. The accruals models show significant results and are more powerful metric to detect earnings management as compared to the deferred taxes in Pakistan.
\end{abstract}

(C) 2015 The authors, under a Creative Commons AttributionNonCommercial 4.0

Corresponding author'semail address:dramirshah@aiou.edu.pk

Recommended citation: Shah, A. M. S. and Shanwari , I. (2015). Detecting Earning Management: Deferred Taxes vs Accruals: A Pakistani Perspective. Journal of Accounting and Finance in Emerging Economies, 1(2)111-134.DOI:https://doi.org/10.26710/jafee.v1i2.68 


\section{Introduction}

Earnings Management is one of the most importantsubject of accounting research which has received a great attention in the past and also quite recently. Detecting earnings management has always been one of the major areas of concern for the researchers and in this regard various researches have been done to define and detect earnings management.There are number of methodologies to detect earning management. Among them accrual based model are on top. The Enron Corp. and WorldCom Inc. show the extent, ability, and willingness of managers to manipulate or miss-state financial accounts.The academic literature has not, until recently, shown that managing earnings to have had a significant effect on the reported earnings(Dechow and Skinner, 2000). This ineffectiveness is in part attributed to methodological issues and also to a lack of focus on capital marketmotivations to manage earnings. This research assesses the use of the Deferred Tax Expense (DTE) to find out and uncover the earnings management. The First objective of the study evaluates the incremental effectiveness of Deferred Tax expense (DTE) as compared to accrual measures in uncovering earning management (EM) to avoid earning decline. Similarly on the otherhand the second objective of the study evaluates the incremental effectiveness of Deferred Tax expense (DTE) as compared to accrual measures in uncovering earning management (EM) to avoid a loss. Thisstudymade two main contributions to the existing literature, using data upon Pakistani firms to add the Pakistani Perspective.First, in employing a novel methodology in Pakistani Scenario, the results have the potential to confirm and strengthen findings based on existing methodology. Secondly, the study investigates earnings management by focusing upon deferred tax provisioning in Pakistan - an area of financial accounting practice which is both relatively complex, highly subjective, and in which, therefore, the opportunity to manage earnings is correspondingly heightened.

The public accounting organizations play a key role in educating accounting professionals. Quality of earnings by and large depends on the management of firm. It is therefore the intention of the management that influences the earnings quality. Intention of management to manipulate earnings may be to achievecertain explicit or implicit objectives and to bring the desired results. But if the management does not influence the accounts or their intentions are not to manipulate the earnings that will in turn positively affect the quality of information generated therefore the quality of earnings will be higher.If there is no earnings management activity it does not mean that information generated is highly reliable and the quality of earnings is high. Earnings Quality is dependent on the disclosures of information in the financial reports, whereas we all know that not all related information can be disclosed in the financial reports.

The regulatory bodies like Security and Exchange Commission (SECs), and the other stake holdersrequire guarantee that the earnings quality, which is reported to them,should be high. In order to achieve higher earnings quality FASB objectives must be kept in mind. It is among one of the Financial Accounting Standard Board (FASB) Conceptual Framework objectives to allow the investors and creditors to make financial decisions of investing and lending. FASB Conceptual Framework emphasizes the reliability, significance and prognostic value of information included in the financial reports.Hence while defining the term earningsquality; all those characteristics mentioned in FASB Conceptual Frame Work must be present in the definition.

Akberet.al (2007) defines earnings quality as "Earnings quality is a measure of the ability of reported earnings to reflect the firm's true earnings and to help predict future earnings."

Although there is some efforts put together to equip the modern managers and the students about the abusive earnings management in companies. Still a lot more needs to be done by the regulatory bodies, 
standard setters and the accounting firms to impart through education the skill to identify the earnings management in the firms. Education is the only way out which would fill the gap of information asymmetry. According to Robinson et al. (1999) study most firms that fraudulently misstate their earnings by resorting to earnings management hired Big Five Public Accounting Firms as auditors. There is need to impart knowledge or earnings manage and the Business and professional publications can play a vital role in this regard (Akers et al, 2007).

Akers et al (2007) in his paper mentioned that auditors hired by firm are in a best position to adjudge the quality of earnings due to their expertise in IAS/IFRS or GAAP, the clients control and their business practices. Hence, they should report on the firm'searnings quality.

Akers et al (2007) argues that the profession has done far less and there is still a lot more to be done on this front in the academia, the professional accounting bodies, regulatory bodies like Securities and Exchange Commission of Pakistan (SECP) in case of Pakistan. Relying on the audit firms to identify any such activity is to happen in rarity as they can or sometimes are party to these activities.

\section{Literature Review}

There have been numerous definitions available for defining Earnings management. Among the researchers Healy and Whalen are the most famous and most quoted for the definition of the earnings management. Paul M. Healy published a paper in 1985 in the Journal of Accounting and Economics. That provided the basis on which all the latest studies are based one way or the other, in fact, all the recent studies are mere extension and refinement of the original Healy 1985 Model.He also published another paper with James M. Wahlen in 1999 in the Journal of Accounting Horizon. Hence, by doing so, they provided the definition for the earnings management and base for latest researches.

Definition of earnings management by Healy and Wahlen (1999):

It is an attempt by the managers to mislead some stakeholders about the economic performance of the company or to influence the outcomes of contracts that may affect their compensation (Healy and Wahlen, 1999).

Beneish(2001)put forward definitions of many authors and provided a very comprehensive literature on earnings management.Beneish (2001) investigated the motivations that lead to earnings management and provided literature about the measurements of earnings management some of the definitions that he quoted are as under:

"The process of taking deliberate steps within the constraints of generally accepted accounting principles to bring about a desired level of reported earnings". (Davidson, Stickeney and Weil, 1987, cited in Schipper 1989 p92 cited in Beneish, 2001 p.2) Or

Hence it is quite evident that how managers while remaining with the legal bounds can bring about desired results from financial reports.

"A purposeful intervention in the external financial reporting process, with the intent of obtaining some private gain (as opposed to say, merely facilitating the neutral operation of the process)...."A minor extension of this definition would encompass" real" earnings management accomplished by timing investment or financing decisions to after reported earnings or some subset of it"(Schipper, 1989, p.192 cited in Beneish, 2001).

From the above definition the purposeful intervention means that the normal transactions are 
intervened,as normally in the actual course of the transaction, it would not be possible to change any results or in other words transaction would bring real or actual results. Hence, in order to get private gain the managers have to intervene. Therefore, by intervening and changing the nature of transaction while remaining within the legal bounds, it would result in changed scenario after the transaction as compared to the actual (real) transaction. If the earnings are managed not remaining within the legal bounds it would be legally called fraud, misstatement or misrepresentation that can be litigated.

All three definitions of earnings management describe it as the discretion used by the managers under the standards to manipulate the accounting information. Managers have incentives and discretion for earnings management. Also according to these definitions earnings management can result, by manipulation at any stage of preparation of the financial or accounting information from transaction to finalization of the financial statements. Earnings management keeps the cover on the true and actual performance of the company from shareholders and others stake holders. Thereforeif we evaluate the performance of a company the earnings are a less reliable measure due to the earnings managements.

If the investors are to rely on the company earnings it would be misleading for them as the opportunistically managing the earnings and the higher motivations to manipulate earnings decrease the value of information due to earnings management activity (Christensen et al. (1999), Marquardt and Wiedman (2004)). The capability of the investors to spot the earnings management and rate them by accounting for the earnings management in their decision making would by and large affect the resource allocation decisions by the investors. The lesser their ability the more prone they would be to the risks of potential poor allocation of resources.

The analysis of earning management reveals that it is pervasive and there are numerous incentive for which the firm managers would use their discretion(Beniesh, 2001), among them the companies while they raise capital are most likely to manage their Earnings, or when they need to meet analyst expectations or bonus plan targets related to executive compensation schemes (Kadan\& Yang, 2004). Firms that nearly meet the expected targets are more prone to manage their earnings. Managers manage the earnings when there is a strong emphasis on them to meet or beat the target expectation (Lee, 2007). Thus the manager resort to the earnings manipulation practices to achieve the targets and hide any decline in earnings or avoiding losses to firms. As the failing to meet the target would bring about bad signaling effects of the firms, and it may result in a decrease in the market price of the shares. Thus, it would bring a decrease in the shareholder wealth. This would also affect the performance of the manager. The dismal performance of the mangers is one of the many other factors the manager resort to smoothening of the earning. The managers are reprimanded for the dismal performance of the firm.Because, among all the indicators earnings or Earnings Per Share is a main performance indicator of the firm. Firms that nearly meet the expected targets are more prone to manipulate and manage earnings. When they need to meet analyst expectations or bonus plan targets related to executive compensation schemes. But also the earnings management in previous studies disregards the fact that market Conditions, like economic growth and industry valuation, are not constant over Time, if we focus on the market conditions can also affect the equity prices and will influence managers' decision to engage in earnings management. (Jiao, Mertens\&Roosenboom, 2007). (Lang) also mention that prior financial disclosures by the firms influence the stock prices, hence the manager would resort to manage their earnings through discretionary accruals.

According to different academic researchers the financial statements incorporate a large effects of earnings management. The share price performance is linked to the manipulation and management of earnings as it is argued it is linked to managerial incentives and the managerial incentives is linked to shares prices (Dechow and Skinner, 2000). The research will bring about more and effective results if 
the focus of the studies is put on the firm's valuation (Ben-HsienBao and Da-Hsien, 2006). According to Yoon (2005) mostly the previous researches focused on earnings management with covering some specific event that would induce the company managers to manage earnings. Companies may be induced to disclose higher earnings in reports if they are having cash flow problems in form of liquidity crunch. Companies face problems in getting loans if their cash flow from operations is hard to come. Despite the low performance the company managers would not like to show a gloomy picture of the company and therefore they manage earnings upward and avoid showing up losses. The credit worthiness of a company and the stock prices has a direct link with the earnings.

In addition to this, company managers at times attempt to downplay earnings to reduce tax obligations or also sometimes to evade political costs when the company is having a good time. The Earning management is also used to manipulate stock prices prior to the grant of stock options (Balsam, Chen, and Sankaraguruswamy, 2007) as the stock option creates incentive to the management to depress the price of the stock before the grant date. (Leuza, ,Nanda, D. Wysocki,, , 2002) accounts for investor protection and hints that argues that the insiders in order to protect their own private control benefit resort to earnings management which means that private investor protection is reduced. The above literature shows that Earnings management affects the share's price from a variety of ways as the stock price, among many other factors, is the indicators of company's worth. The value of stock is determined by the earning power of the firms. So the earning management is used to manipulate the stock prices to achieve various objectives by the managements. Howeve, $r$ it is predominantly evident that presence of large institutional investor on board of director dose affects the earning management decision by serving as a check and therefore a constraint on manager discretion (R. Chung et al. 2002). There is also evidence of using discretion to avoid loss or income declines in publicly held financial institution like bank Beatty (2002). Beatty (2002) wrote papers in 1998 which was published in the Review of Accounting Studies in 2002. The study concluded that higher number of companies were showing a small increase in their earning relative to higher number of firm which shows small earnings declines. The study was conducted on the publicly and privately held banks. These higher frequencies around the earnings threshold were attributed to earnings management.

A phenomenon of Earnings Management (EM) is not easy to be detected from the company's annual financial reports. The reason of this is that the propensity of such activity to be undetectable. EM can only be considered successful if it is undetectable. Previous researchers worked on earnings management detection and their focus was on the accounting techniques and methods which were changed.These changes were generally easily observable to outsiders. This study is distinctlydifferent in this manner to more recent studiesthat are done with accruals, which has found that many times the market does not rate accrual and therefore the earnings management goes unnoticed (Healy and Wahlen, 1999). It is very difficult to find a method which can find how earnings management goes undetected by the market. The researches attack the problem from different angle as they take these phenomena in general whereas the investor looks it as a single case and single object. Studies or researches are normally based on a large data set and thus it is difficult to observe and analyze the systematic patterns, which if look at as a single case scenario may seem random.

Researchers first develop a hypothesis about the presence of earnings management and thanapply different appropriate tests to investigate where it is present. Mostly the recent researches these tests are applied on accruals which is presumed to be subject to managerial discretion we call it discretionary accruals or abnormal accruals.Number of models have been presentedby various researchers to detect earning management but the accrual models are used more than any other model to detect earning management in researches on earnings management.Healy (1985) used mean of total accruals which were divided by earlierperiod ( $\mathrm{t}-1)$ total assets across the partitioning variables. Healy partitioning 
variable divided observations in three groups in which one group predicted to have managed earnings upward while the other two groups managed earnings downward.There are two points defined by Dechow et al (1995) in his study which are namely estimation period and the event period. Observations set of which earnings isexpected to be manage downward is tremendous an event period and the other observation set, the earnings of which is expected to be manage upward is called estimation period.DeAngelo model uses earlier period total accruals that are divided by the previous years' total assets as a metric for nondiscretionary accruals. As this model uses differences in the total accruals with the assumption of first differences has an expected zero value in $\mathrm{H}_{0}$ of no earnings management. Like Healy (1985) in DeAngelo Model the estimation of nondiscretionary accruals are restricted to previous years' observations. To proxy the non-discretionary part of accruals both the model employ total accruals from the inference period. If the nondiscretionary component of the accruals isnot changing over a period of time and discretionary component of the accruals possess a zero average or the mean in the period named as estimation period. These models will determine the nondiscretionary component of accruals with complete accuracy but in both the total accrual models it willproduce error for the calculation of nondiscretionary part of the accruals if nondiscretionary part of the accruals changes over period of time.Consistent withDechow et al. (1995)Healy (1985) is effective if nondiscretionary accruals keep to a white noise process around a constant mean whereas DeAngelo (1986) method is effective if nondiscretionary accruals keep to a random walk. These two models are based on the postulation that the nondiscretionary accruals remainsteadyover a period of time and does not change, which is unlikely. The accruals accountings process changes the nondiscretionary accruals as the economic environment change. The changes in the economic environment are therefore not accounted for in the Healy(1985) and DeAngelo (1986) Models. Secondly a firm may face abnormal situations which cannot be captured with the both total accrual models.Dechow and Sloan (1991) used industry model which is same as the Jones Model. It also incorporates a change for the variation in nondiscretionary accruals as we all know that nondiscretionary accruals change over the course of time and does not remain constant. As it was earlier mentioned the Healy (1985) \&DeAngelo (1986) models which assumed nondiscretionary accruals to remain steady over time.

The industry model holds the assumptionthat change in the determinants of nondiscretionary component of the accruals common transversely incompanies in same industry.Jonesintroduced a new model in which the assumption of constant nondiscretionary accruals was relaxed. He used regression of total accruals on elements that brings aboutvariations in company'sfiscal and financial surroundings to spotthe management of earnings, and uses the residualas asurrogate for abnormal accruals.Jones Models incorporated the outcomes of variations in the company's financial environment on nondiscretionary accruals.Jones assumes that the revenues are nondiscretionary component and therefore with this implicit assumption the Jones Model produces a biased estimate. The manager sometimes use revenues to manage earnings as they book revenue by dummy invoicing or when the revenue was not to be recognized and accrue revenue that would result in the cash or payment is yet to be received therefore there is increase in accounts receivable. With this limitation the estimates produced are biased.Adjustments were provided by Dechow et al (1995) for discretions used in accruing revenue when there is doubt about the observance of revenue recognition criteria. The non-conformance to observe revenue recognition criteria results in error in Jones Methodology. This Methodology eliminated error produced by Jones (1991) methodology and therefore incorporated for the discretion used in the revenues.The Modified Jones Model providesa slight adjustment to the Jones Original Model as it provides adjustment for the change in revenue and for variations in receivables in period of event. This model is built on presumptionthat all variations in the credit sales are flexible and subject to discretionary.Credit sales are argued to have been subject to management of earnings with more ease than that of cash sales. Hence it is easy to use discretion in case of credit sales as compared to the cash sales in which the discretion cannot easily be exercised by the firm managers. In the Jones Original 
Model it was implicitly assumed that discretion for revenues is not used in the period of event. However, in absolute terms, the two models have a very low power for earnings management. The probability may range from $01 \%$ to $05 \%$ of total assets. In addition, these two models show very poor results for extreme financial performances which therefore miss-specify them, with each model producing a significant proportion of Type-I errors when applied to companies with excessive cash flows. Results cast doubt at the effectiveness of these two i.e. standardJones and modifiedJones methodologies isolating accruals manipulation. Wayne R. Guay, R. P . Kothari and Ross published a paper in USA in 1996. He with the left out sample of 1450 firm and 31,372 firms years observation produced a result consistent with this skeptical viewevaluated the both models using a marketbased procedure and according to his results among all accruals model neither of the model generates a reliable measure of accrual management. This study cast doubts on the reliability of the accrual models as all the previous studies showed reliably significant results but this study provided an impetus for the researchers to find out more avenues, or other more refined models to measure the ever dominating phenomena of earnings management. Hence there is still a need of more refined and accurate model to measure the earnings management. To alleviate the measurement errors linked to the discretionary accruals, Larcker\& Richardson (2004) made slight adjustment and added the book-to-market ratio and operating cash flows to equation of modified Jones equation.

The projected growth in the operations is controlled through Book to market ratio and if the projected growth is missed out and left uncontrolled discretionary accruals will account for that. To capture the operating performance of current year Cash Flow from the operations is present. Dechow et al (1995) argues that both the models miss-specifies the discretionary accruals if the company's financial performance is extreme, hence the CFO is added as.Larker\& Richardson (2004) has provided a model which according to them has a better explanatory power to the modified Jones model;it spots the unpredicted accruals which are less constant then other factors of earnings. Their models spot earnings management as per SEC enforcement actions and distinguish discretionary accrual which is linked to low future earnings \& low future share returns.Extreme performance by companies can lead to errors in the detection of earnings manage. According to Kothari et al. (2005) the unexpected and extreme performance are systematically non zero and thus the company's performance is related to accruals. Two methods were tested by Kothari et al. (2005) to account for the company's performance with the discretionary accruals. Return on Assets (ROA) adds a supplementary independent variable in the regression. The results of that study suggest thecurrent period ROA as the better measure than matching on the prior year ROA. Hence it is concluded that this is a superior measure than to include performance variables to the discretionary accruals regression.Beneish (1999) used a relatively different sample of firms. He took a sample of all those companies which received SEC's enforcement action and companies which were identified by news media as the one who managed there earnings. He used a probit model to spot the earnings management with different variables of financial reports and statements.

The model used by him is not liketraditional models but the model is adopted for the purposespotting earnings management.The model provided result that shows associationof the likelihood of earnings management with selected variables from the financial statements.

McNichols (2000) mentioned Aggregate accrual models that does not take into the account the long term earnings growth are miss-specified.The miss-specification therefore can lead to confusing results and deductions in the earnings management behaviors.

DeFond and Jiambalvo (1994) and Teoh et al. (1998) has also endeavored to further refine and make it 
more effective model. They worked it out with working capital components of the total accruals. Two authorsi.eBeneish (1998) \& Young (1999) has put forward that this is more appealing formula as it is a year to year basis management of earnings with depreciation. Accruals areexpected to have limited capability.

In addition, Young (1999) reports that Jones style models based on a measure of total accruals (i.e., inclusive of the depreciation charge) induce substantial measurement inaccuracies in the resulting estimate of accruals that are managed. Lastly original timeseries model of the Jones and modifiedJones methodologies proven to have limited efficacy when we implement the formulas empirically because of the need for a sufficiency of data for thelong timeseries to enable an estimation which is effective for the firststage regression parameters.

This constraint has brought about several apprehensions as problem of survivorship bias naturally turn up and the assumption of stationarity over time for the coefficient estimates of REV and PPE might not stay appropriate.Lastlythere is a characteristic of accruals in which the accruals reverses that may also bring a specification problem in the form of serial correlation in residuals. To rid those issues, a recent study by Becker et al (1998); Subramanyam, (1996); DeFond and Jiambalvo, (1994) used a cross sectional models.

Philips et al (2003) provides evidence of temporary differences arise book and tax income which can also be used to spot the earnings management. It is very common that income tax liability in a period of account does not represent the total tax consequences. A separate IAS i.e. IAS 12 Incomes Taxes, is available to capture the total tax consequences of transactions recognized in reporting. IAS 12 delineates how to recognize the transactions and its future and current consequences. IAS 12 requires that the total consequences of the a period of account and any other event be recognized in the same period of account in which these transactions and their consequences and any other event fall.If there is an increase in the deferred tax liability it mean the company is either currently recognizing revenue or is deferring some of its discretionary expenses for accounting purpose. A deferred tax liability arises in balance sheet due to such revenue recognition or deferrals of expenses and a deferred tax expense later on in statement of comprehensive income. Similarly, if the company is deferring to recognize its revenue or recognize expenses now in such a case it would result in deferred tax assets on the statement of financial position future deductible amounts. These are done in the company own accounts and has nothing to do the tax accounts as they may vary according to tax authority rules and regulations. Exceptions are in case of merger, acquisition, divestitures. The change in deferred tax liability results in deferred tax expense in statement of comprehensive income.

Temporary book tax differences is used to spot earnings management (Philips et al, 2003). As there are differences in thecarrying value of an asset and tax base that are recognized in period of account to which it belongs to. Phillips et al (2003) has developed a hypothesis based on which it concluded that deferred tax expense is incrementally useful as compared to accrual measures in detecting earnings management.

If go further deep the deferred tax can also be managed because the standards require that the deferred tax assets can only be recognized if there is probable future tax liabilities and profits available against which this asset can be used. Schrand and Wong 2003;Pincus, Rego and Wang, 2004; Frank and Rego 2005; Phillips investigated the deferred tax asset account valuation account (VAA) but they found some rather contradictory results. Even though there results are contradictory, but as the standards provide managers the discretions managers can use it to manage earnings. Thus the deferred tax expense which Phillips et al (2003) used as the proxy for the earnings management may also be managed by the 
managers as we mentioned earlier they under the standards have discretion to do so.

Predominantly accruals models have been used more often than cash.Manager Discretion to manage earning can also be detected by a very useful metric i.e. deferred tax expense. The deferred tax expense has also been used as a last resort to manage earnings while managers strive to meet the earning targets, as the Dhaliwal. D. S et al 2004, published paper in Journal of Contemporary Accounting Research in 2004. He conducted a study on 14,938firmsyears which included all the choice variables in that paper he also concluded that companies that has accruals higher than normal would also be more prone to use taxes to manipulate earnings to meet earnings targets. The companies that have lower projected effective tax rates by missing the agreed prediction it is therefore consistent that companies will decrease the expense on account of tax if earning management is not accomplished from other sources and would therefore lower the tax to meet earnings targets. When the tax on income is more than the actual tax payment the deferred tax liability arises. It normally happens when the booked income exceeds the taxable income. The excess amount is the liability to be paid to income tax authorities and therefore is recognized as liability in the balance sheet of the company.Deferred tax is used as metric my managers to prevent fall in earnings, to prevent loss and to beat or meat expectations of the analysts (Philips et al, 2003). Philips et al (2003) have used deferred tax expense to spot earning management. The study also evaluated application of the same research in Pakistan by evaluating the effectiveness and efficacy of the deferred tax expense in identifying the earnings management in Pakistan and to test the results to see whether the results from the methodology used by Philips et al (2003) also applies to Pakistan.

In order to detect the earning management through deferred tax two hypotheses have been developed following the Burgstahler\&Dichevs (1997) \& Philips et al (2003). Burgstahler\&Dichevs (1997) used three intervals for earning changes i.e from 0 to $0.005,0.01 \& 0.015$ to show how the firms behave in avoiding earning decline and for earning levels they used intervals from 0 to $0.01,0.02 \& 0.03$ to show how the firms behave to avoiding loss. As a result of this according to Burgstathaler\&Dichves (1997) findings a higher frequency of firms falls in interval of zero and small increase in annual scaled earning changes to the slightly negative earning changes interval and similarly the higher frequency of firms falling in the earning interval of 0 (Zero) and slightly positive earning intervals as opposed to slightly negative earning intervals. Hence based on above and consistent with the Philips et al (2003) we have selected the middle range that is from(- -0.01 to 0$)$ and (0 to 0.01$)$, for avoiding earning decline. Similarly,it is (-0.02 to 0$)$ and (0 to 0.02 ) for avoiding loss. Consistent with the Philips et al (2003), following are the hypothesis. This study replicated the Figure 01 for avoiding the earnings decline and to show the findings of the Burgstathaler\&Dichves (1997) \& Philips et al (2003). We found it again consistent with the previous researches and finding a large number of firms falling in the 0 to 0.01 as compared to -0.01 to 0 which is evident form the Figure 01. Similarly the Figure 02 has been replicated for the frequency of firms for avoiding loss again the results have been found consistent with the previous researches of Burgstathaler\&Dichves (1997) \& Philips et al (2003) and the large number of firm falls in the 0 to 0.02 range as compared to -0.02 to 0 scaled intervals of earning.

H1: Deferred Tax expense is incrementally useful as compared to accrual measures in detecting earning management to avoid earning decline.

H2: Deferred Tax expense is incrementally useful as compared to accrual measures in detecting earning management to avoid a loss.

\section{Accounting Development and Corporate tax environment in Pakistan}

Junaid Ashraf \&Waqar I. Ghani wrote papers in the international Journal of Accounting on the subject of accounting development in Pakistan in 2005. According to Junaid, (2005) for more than three decades "The Colonial Companies Act 1913"was in force in Pakistan till the Companies Ordinance 
1984promulgation and has shaped the accounting development in that period. He also mentioned the role of the Asian Development Bank (ADB) and The International Monetary Fund (IMF) in determining the accounting development in Pakistan. Although the standards were readily adopted in Pakistan in 1985 but despite adopting the IAS an IFRS the quality of the reporting the financial did not improve. The failure has been attributed to the enforcement mechanism in Pakistan as Junaid, (2005) argues that the interaction among the legal, accounting and the sub-systems in the accounting information systems needs to be specifically addressed for the developing countries like Pakistan. The Standards may be readily adopted for the developed countries but special attention must be paid to devise method for the adoption of the standards in the developing countries like Pakistan to improve the quality of the financial statements and the reportingwith accounting systems.

More fifty percent of listed companies at Karachi Stock Exchange (KSE) are owned by single family (Junaid, 2005). An Incentive has been provided in the Income Tax Ordinance 2001 for listing of the companies at Karachi Stock exchange to pay low taxes as compared to the unlisted companies. Despite the low taxes the tax evasion has been very common in the family owned companies.It has risen; as percentage of the Gross Domestic Product (GDP) for the last seven years rose to11.4\% from 10.6\% (Junaid, 2005). In many cases triple financial reporting (i.e three types of financial statements are prepared) is done in many developing countries like Pakistan. Even though the government has imposed $0.5 \%$ turnover tax on corporations irrespective of profit or loss but still the tax evasion by group of companies owned by single family is very common and pervasive in Pakistan.

The managers have greater discretion to manage earningsunder Pakistan's accounting standards than would allow Income tax authorities under Income Tax Ordinance 2001(tax rules).For example income tax authorities would not allow provisionssuch as depreciation, bad debts, the revenue recognition method may cause temporary book tax differences, the accountant and the company managersmake provisions forwarranties, post-retirement benefits, self-insurance, restructuring and reserves generate temporary book tax differences while accounts payable, receivable, wages payable are subject to less discretion of manager under tax laws than Local Accounting Standards. The temporary book tax differences will isolatejudgmentsused by managers form non-discretionary choices (Philips et al 2003). Timing differencesis a result of different reporting rules under each system. Accounting Standards allow greater discretion to managers. The manager's discretionary choices may create a permanent or temporary book tax differences. This paper will tests the accrual measure as compared to the deferred tax to investigate which of the metric is more useful at to detect earning management for firms that avoid earning decline or avoid losses while engaging in earnings management. The deferred tax is that part of the firm's income tax expense which belongs to current period but will be paid in a later period. The tax amount is measured on the basis of accruals so the liability would be created if the current period income is more than the income which is computed for tax purposes hence it would lead to deferred expense. There is less discretion available for mangers to manage earning under the income tax rules and therefore the managers would resort to the National standards to manage earnings while striving to achieve their earnings thresholds (Mills \& Newberry, 2001), (Manzon\&Plesko. 2002), (Hanlon, 2002), (Joos et al, 2002), (Plesko, 2002 in Philips et al, 2003). Hence the deferred tax is helpful in detecting the earning management.

\section{Research Methodology}

The portion of paper develops research hypotheses of the study.It explains the models used for empirical research. It provides an operational definition of all the variables used in the models.It also provides sample selection and data collection methods. The research design utilizes information from published financial statements in order to identify the occurrence and extent of under- and over-provision for 
deferred taxation as it would lead to increased probability of earning management along with the other accruals and changes in cash flows as control variables.

We argue that the managers have greater discretion in the reporting and managing the earnings under Accounting Standards than tax rules \&regulations rules and they therefore try to manage earnings upwards if it is falling or they manage earnings to avoid the losses. While managing the earnings upwards to avoid decline in earnings or showing decline in earnings mangers would not let the current tax expense to increase. Similarly, in managing the earnings to a level that it does not fall the manger use earnings management techniques to avoid loss while keeping tax cost minimum as they may have a limited amount of loss to carry forward.

Previous researches have used various accrual models to measure the earnings management. Different researchers have used different measures to proxy the irregular accruals. Healy (1985) employed total accruals, Jones (1991) employed the residuals as abnormal accrual or a substitute for earnings management from total accruals regression and forward looking model Dechow et al (1995) modified Jones (1991) model and provided adjustment for the revenue recognition criteria through adding one more variable that is the growth in the revenue. Among these accrual models the forward looking model is the most effective (Dechow et al, 1995). Jones and Modified models can better measure the abnormality in accruals and therefore the earnings management and identify use of mangers discretions Gauy et al (1995). However a research as mentioned in the Philips et al (2003) by Bernard and Skinner (1996) misclassify the normal accruals as abnormal. Hence that suggests that accrual or abnormal accruals ability to or effectiveness of this metric to detect the earnings management is not reliable.

\subsection{Sample Size:}

Initially, all six hundred and fifty listed firms on Karachi Stock Exchange (KSE) were selected as sample. Later these firms were scrutinized as to the inclusion of deferred tax expense in their financial statements. Ultimately, only fifty eight firms were selected for analysis having deferred tax expense on their financial statements. Therefore, firms that had no deferred tax on their balance sheet were excluded. International firms,financial sectors firms were also excluded due to variation in financial reporting. Financial statements of the financial sector firms differ in great deal from the non-financial corporate sector firms; like the nature of the account receivables differs from that of the other corporate sectors.

The sample selected on the basis of convenience sampling as the data availability regarding deferred tax became the constraints in the data collection.

\subsection{Data Collection:}

This study used secondary data for empirical analysis. Data collected from the financial reports for the year 2005to 2009. The study used pooled cross sectional data. The period of study has been kept to five years as the data before 2005 was not available. The period under the study is post 2001 as amended Income Tax Ordinance was promulgated in 2001. The data has been extracted from the financial reports as the only available source for the deferred component of tax in Pakistan.

\subsection{Mathematical Model:}

The probit regression is used because the dependent variable is dichotomous. The ordinary least square regression may lead to inappropriate results. This study used a probit regression model following Phillips et al (2003). Empirical analysis conducted using pooled cross sectional data:

$\mathrm{EM}_{\mathrm{it}}=\alpha+\beta_{1} \mathrm{DTE}_{\mathrm{it}}+\beta_{2} \mathrm{ACC}_{\mathrm{it}}+\beta_{3} \Delta \mathrm{CFO}_{\mathrm{it}}+\dot{\varepsilon}$

Where 


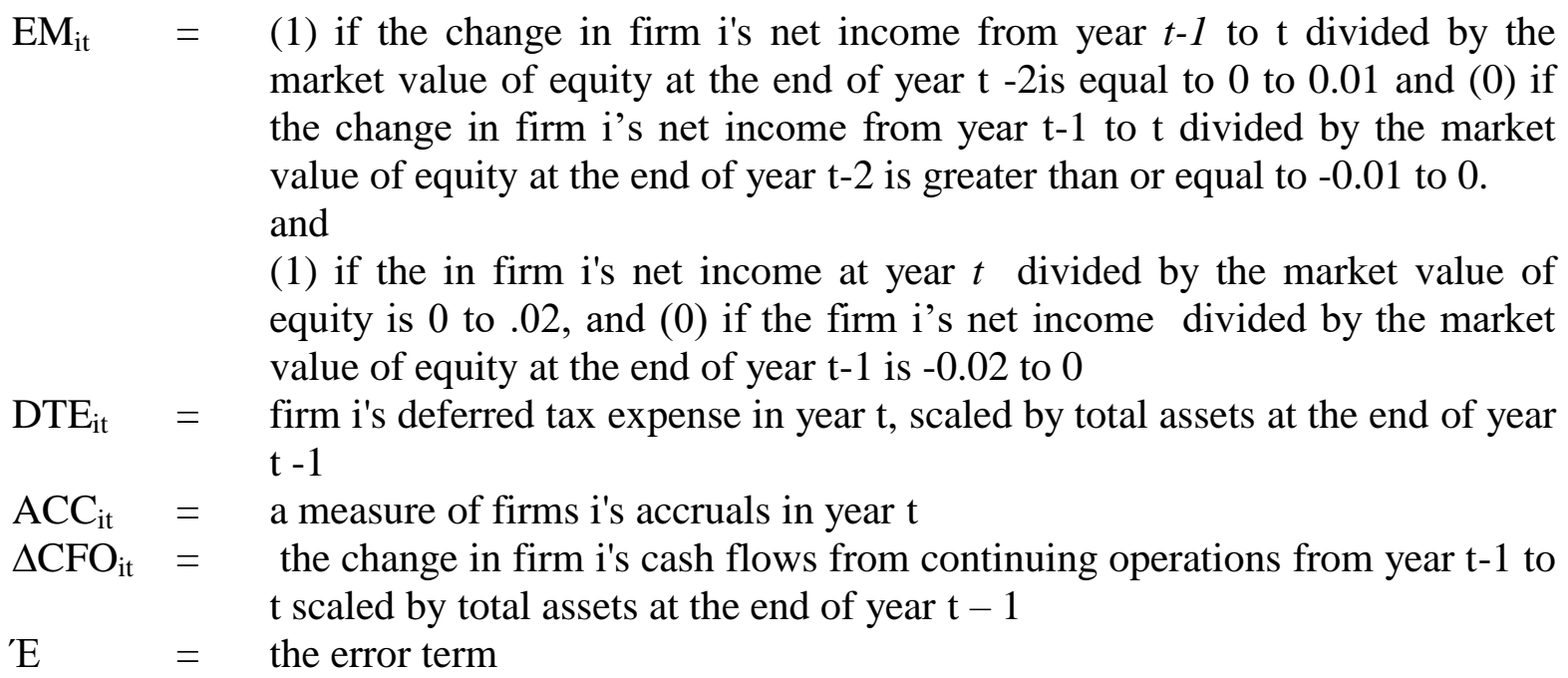

\subsection{Variables:}

\section{- Earnings Management}

Since EM is binary dependent variable a probit regression model is used. Logit regression model can also be used but as Philips et al (2003) used probit model this study would use the same model to evaluate results of the Phlips et al (2003) study. The selection criterion for the sample companies to be used in analysis for (1) avoiding the earnings decline; the firm years generated range of firm years from 181 to 79 . More than $61 \%$ of the firms years scaled earning changes that fell from zero or slightly positive i.e $\geq 0$ to $<0.01$ or $\mathrm{EM}_{1}=1$.

Similarly the sample for the earnings management of the avoiding loss; is selected using same criterion and the sample size for this analysis range from 181 to 87 firm years. This becomes the sample of firms years for the study probit regression analysis of (2) avoiding loss. Approximately $87 \%$ of the firms sample fell in the zero or slightly positive i.e $\geq 0$ to $<0.02$ or $\mathrm{EM}_{2}=1$. The sample also includes the just missed sample i.e. $\geq-0.02$ to $<0$ or $\mathrm{EM}_{2}=0$ as control variable. 


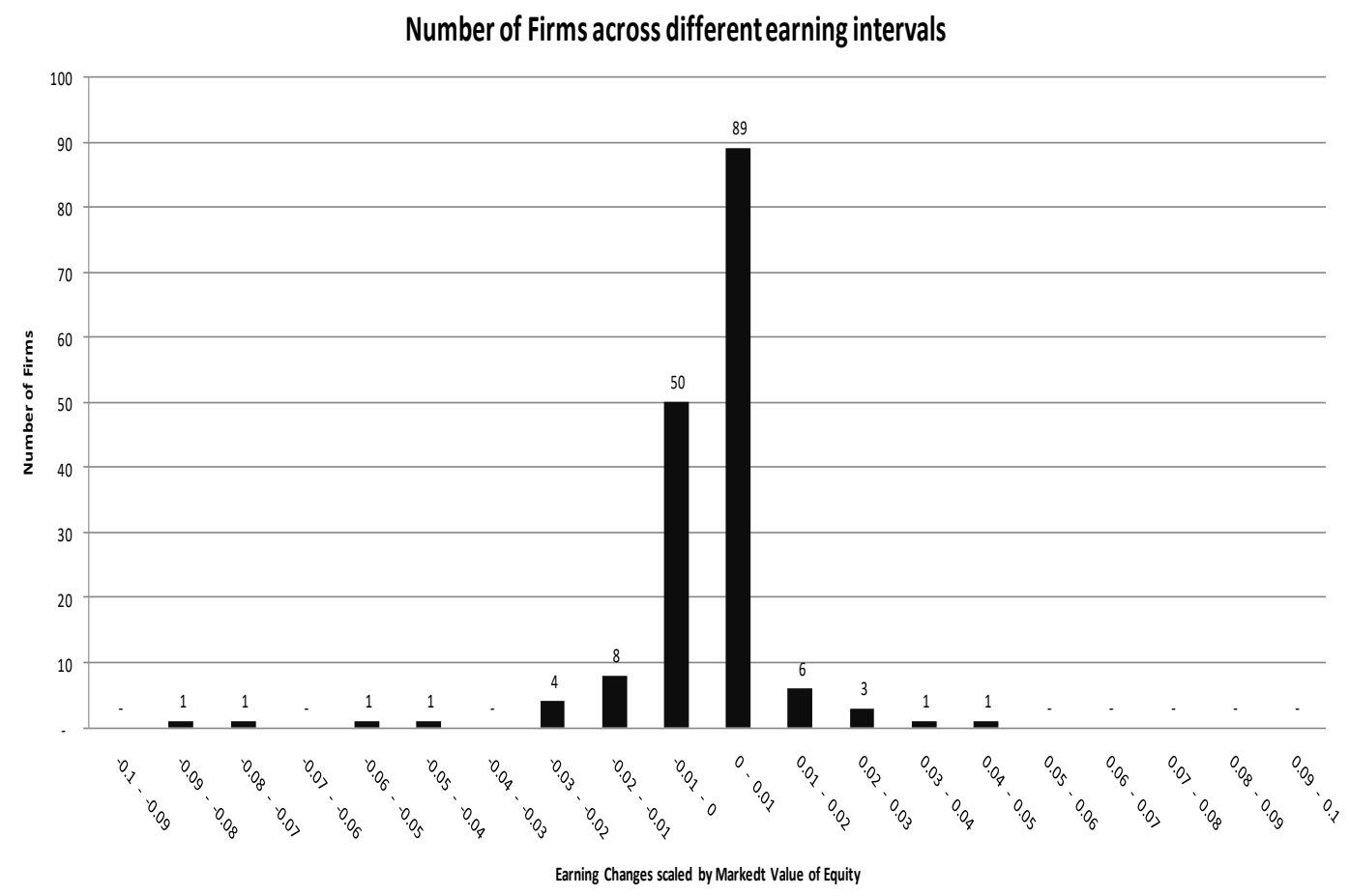

Number of firms across different earning intervals

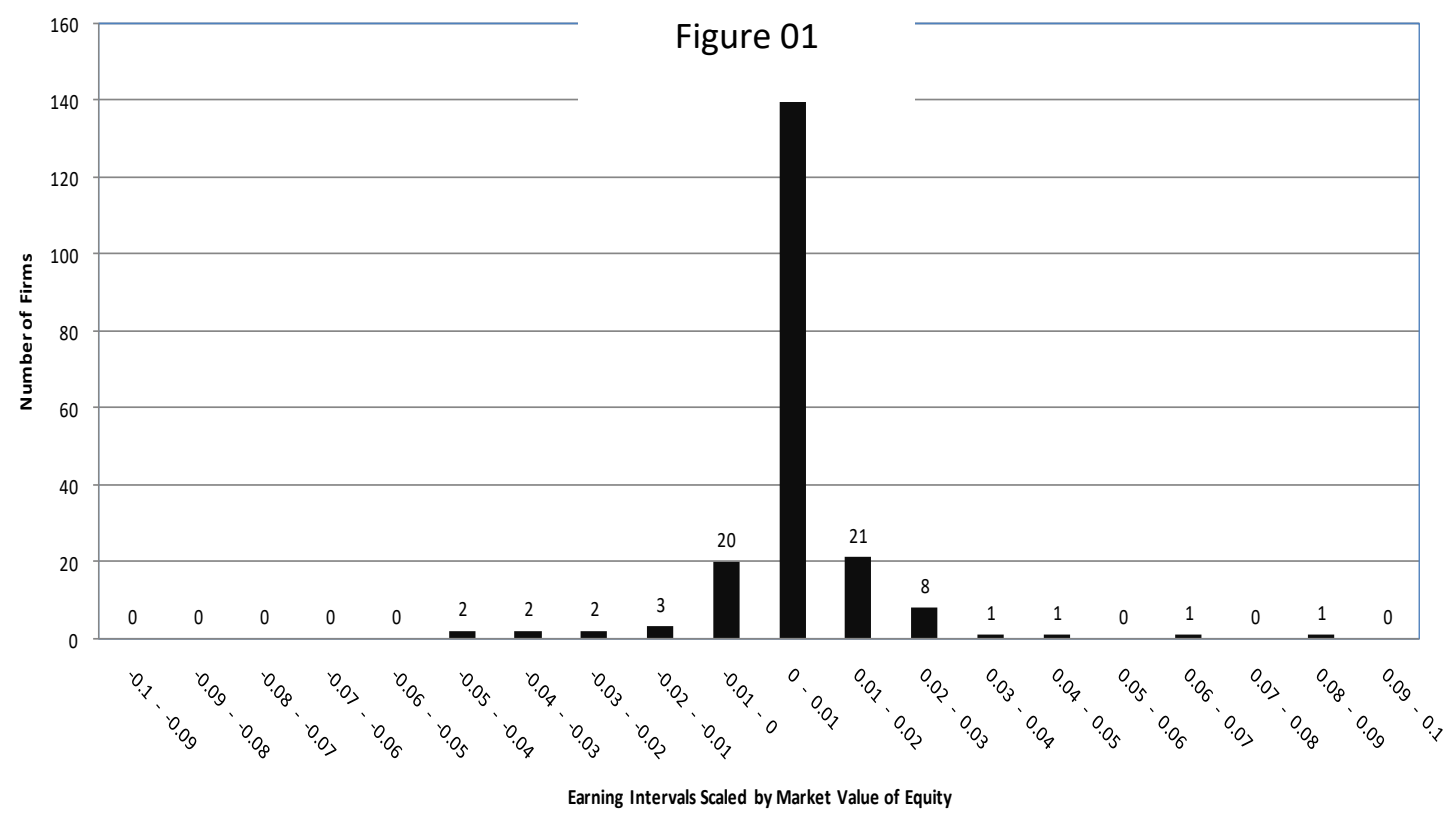

Figure 02

\section{- Deferred Tax Expense}

The deferred tax expense is taken as the proxy for the book tax difference and will be computed as per the statement of the financial accounting standard board (SFAS 109 (FASB 1992). That would use the balance sheet approach for deferred tax expense this is in conformity with Philips et al (2003). According to Statement of Financial Accounting Standard board 109 the temporary differences are to reverse in future whereas the other difference i.e permanent difference will not reverse. The temporary differences will either cause temporary deferred tax assets or liabilities. If firms are resorting to 
recognizing revenue or defer some expenses whereas the same is not allowed under the tax rulings, it would lead to deferred tax liabilities which will be a deductible from income in future. According to Philips et al (2003) the net increase in the current liabilities of deferred tax would result in allowing firms to show more pre-tax incomes and lesser the liabilities of deferred tax they would show less pretax incomes. The deferred tax expense or benefit is equal to the difference of two periods (SFAS 109). In this study the deferred tax expense is taken as substitute for the book tax variances and a metric or one variable for investigating the usefulness of the variable in detecting the earning management while manager strive to achieve earning threshold.

Along with the two hypotheses above Philips et al (2003) also developed and tested a third hypotheses but as the information and data about analysts forecast in not available in Pakistan so it is not possible at this stage to test the third hypotheses. Hence we will not be taking into account the third hypotheses of the (Phillips et al, 2003). FollowingPhilips et al, (2003) earning management model to investigate earning management to prevent a fall in earnings and to prevent loss with the help of deferred tax expense and three accruals as proxy for earning management the three accruals includes Healy, Jones and forward looking Model.

\section{- Accruals}

ACCit is computed with the three accrual models which are Healy (1985) Total Accruals, Jones (1991) Abnormal accruals model and the Forward Looking Model. This study used all three accruals model. The Accruals, Deferred Tax Expense (DTE) and $\Delta$ in CFO are scaled by lagged total assets which are in conformity with the Philips et al (2003).

To calculate the ACCit for the probit model, any of the three models i.e. Healy, Jones and Forward looking model is used to testtheACCit each time for Hypotheses. Following the Philips et al (2003) \& Healy (1985)calculation of total accruals is done through following model which has been used extensively in previous researches.

Or

$$
\mathrm{TA}_{\mathrm{it}}=\mathrm{EBEI}_{\mathrm{it}}-\left(\mathrm{CFO}_{\mathrm{it}}-\mathrm{EIDO}_{\mathrm{it}}\right)
$$

$$
\mathrm{TA}_{\mathrm{it}}=\mathrm{EBIT}_{\mathrm{it}}-\mathrm{CFO}_{\mathrm{it}}
$$

TA $_{\text {it }}=$ Firm i's total accrual in year $\mathrm{t}$

$\mathrm{EBEI}_{\mathrm{it}} \quad=$ firm i's income before extraordinary items in year $\mathrm{t}$

$\mathrm{CFO}_{\mathrm{it}} \quad=$ firm i's cash flows from operations in year $\mathrm{t}$

$\mathrm{EIDO}_{\mathrm{it}} \quad=$ firm i's extraordinary items and discontinued operations from the statement of cash flows in year $\mathrm{t}$

\section{- Modified Jones Model}

As Dechow et al (1995) discussed a limitations of the Jones Model in which it was argued that it cannot capture the effects of manipulation based on sales, due tochanges in revenue or sales, it is assumed,that nondiscretionary accruals will rise. Hence to account for the manipulation that is based on sales, Dechow et al (1995) suggested anadjustment to Jones model. Both Models are same exceptthat the change in debtors $(\triangle \mathrm{REC})$ is subtracted from $(\triangle \mathrm{REV})$ at $2^{\text {nd }}$ stage. Thereforein this model it is implicitly assumed that all changes in credit sales in the event period result from EM.In tests comparing the power both models the modified Jones Model indeed significantly better spotearnings management that is based on sales (Dechow et al, 1995). 


$$
\mathrm{TA}_{\text {ccit }}=\alpha+\beta_{1}\left(\Delta \text { Sales }_{\mathrm{it}}-\Delta \mathrm{AR}_{\mathrm{it}}\right)+\beta_{2} \mathrm{PPE}_{\mathrm{it}}+\dot{\varepsilon}
$$

$\begin{array}{lll}\triangle \text { Sales }_{i t} & = & \text { the change in firm i's sales from year } \mathrm{t}-1 \text { to } \mathrm{t} \\ \Delta \mathrm{AR}_{\mathrm{it}} & = & \text { the change in firm i's accounts receivable from operating activities from } \\ & & \text { year } \mathrm{t}-1 \text { to } \mathrm{t} \\ \mathrm{PPE}_{\mathrm{it}} & = & \text { firm i's year } \mathrm{t} \text { gross property, plant, and equipment } \\ { }^{\mathrm{E}} & = & \text { the error term }\end{array}$

\section{- Forward looking model}

Three adjustments have been made in the forward looking model models. First not all the increase in the credit sales is considered normal instead a part of the increase in the credit sales is considered as normal accruals. This is done by regressing the change in the accounts receivable on change in sales. The second change is in the portion of total accruals as it is assumed as predictable and are scaled by lagged total accruals of ( $\mathrm{t}-2)$. Third is addition of future sales growth which accounts for the abnormal increases in the inventories in the wake of anticipated higher sales. The future sales growth would neutralize the effect of discretion used in managing inventories. The future data of sales will be used to arrive at the normal accruals with this model.

$$
\mathrm{TA}_{\mathrm{it}}=\alpha+\beta_{1}\left(\Delta \text { Sales }_{\mathrm{it}}-(1-\mathrm{k}) \Delta \mathrm{AR}_{\mathrm{it}}\right)+\beta_{2} \mathrm{PPE}_{\mathrm{it}}+\beta_{3} \mathrm{TAcc}_{\mathrm{it}-1}+\beta_{4} \text { Sales }_{\mathrm{it}+1}+\dot{\varepsilon}
$$

$\Delta$ Sales $_{i t}=$ It is the change in firm i's sales from year $\mathrm{t}-1$ to $\mathrm{t}$

$\Delta \mathrm{AR}_{\mathrm{it}}=$ the change in firm i's accounts receivable from operating activities from year $\mathrm{t}-1$ to $\mathrm{t}$

$\beta_{2} \mathrm{PPE}_{\mathrm{it}}=$ firm i's year $\mathrm{t}$ gross property, plant, and equipment

$\mathrm{k}=$ the slope coefficient from a regression of $\Delta \mathrm{AR}_{\mathrm{it}}$ on $\Delta \mathrm{Sales}_{\mathrm{it}}$

$\mathrm{TA}_{\mathrm{it}-1}=$ firm i's total accruals from the prior year, scaled by year $\mathrm{t}-2$ total assets

Sales $_{i t+1}=$ the change in firm i's sales from year $\mathrm{t}$ to $\mathrm{t}+1$, scaled by year $\mathrm{t}$ sales

$\dot{\varepsilon} \quad=$ the error term

\section{Analysis and Discussion}

We can graphically trace the evidence of the relationship between the deferred tax expense scaled by the total assets with the earnings changes and earnings levels at and around the earnings thresholds. The same has been shown in the figure 04. The Figure 04 is showing a histogram of the mean deferred tax expense with the changes in the earnings scaled by the market value of equity that fall in with the interval of 0.01 of market value and range from -0.10 to 0.10 . We can see that mean deferred tax expense(DTE) for the earning interval of 0 to 0.01 that is in the range of slightly positive or zero earning changes interval is 0.004. Similarly mean deferred tax expense (DTE) for the just missed interval that is the interval of earning changes that fall in -0.01 to 0 is -0.003 .Results are consistent with the Philips et al study (2003).Following the Philips et al (2003) we have also plotted graphically Total Accruals to interval of earnings changes and found that mean total accruals increases in the zero and slightly positive earnings changes interval the results have not been shown in this study.

Similarly the histogram for the mean deferred tax expense by scaled earnings levels have been shown in Figure 05. The scaled earnings levels have the interval of 0.01 and the range is from -0.10 to 0.10 . As it has been mention in the previous research of Philips et al (2003) that due to the tax benefits of losses, the mean deferred tax expense (DTE) is negative for all loss intervals but it becomes positive for the earnings interval of zero or slightly positive. The mean deferred tax expense for the zero and slightly positive earnings intervals is 0.004 where as it is -0.007 for the earnings levels of slightly negative 
interval.
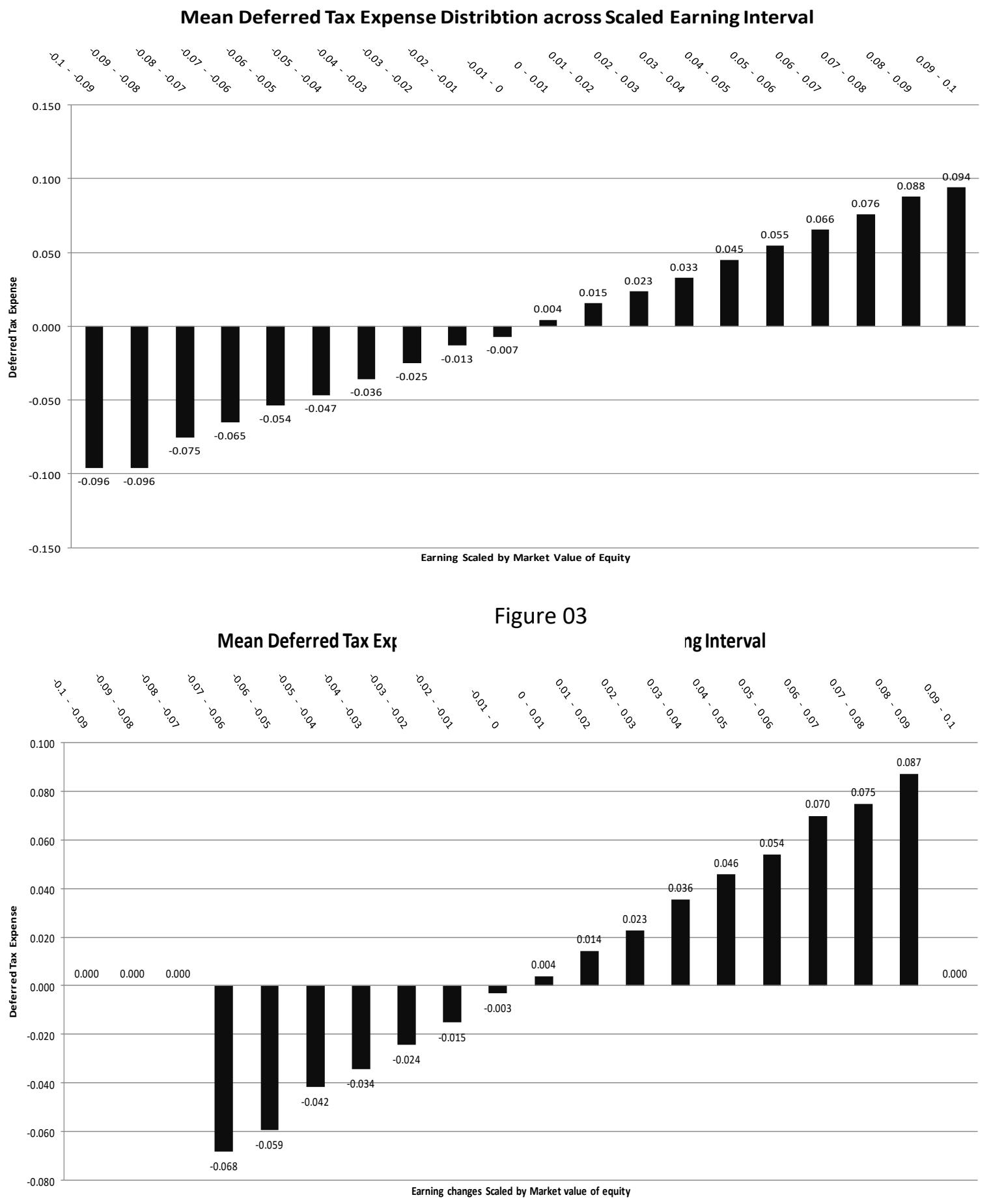

Figure 04 


\begin{tabular}{|c|c|c|c|c|c|}
\hline \multicolumn{6}{|c|}{ Table 01} \\
\hline \multicolumn{6}{|c|}{$\begin{array}{c}\text { Table } 01 \\
\text { Descriptive Statistics }\end{array}$} \\
\hline \multicolumn{6}{|c|}{$\begin{array}{l}\text { Panel 01: The Samples of earnings management to avoid a decline in the earnings include zero and slightly positive earnings changes which is clasified as } E M=1 \text { vs slightly } \\
\left.\left.\text { negative earnings changes that are clasified as } E M=0 \text {. The firms years of } E M=1 \text { include scaled earning changes[( } \mathrm{NI}_{\mathrm{t}}-\mathrm{N}_{(\mathrm{t}-1)}\right) / \mathrm{MVE}_{(\mathrm{t}-2)}\right] \text { equal to } 0 \text { or less than } 0.01 \text { and the firms } \\
\text { years of } E M=0 \text { includes scaled earnings changes of greater than }-0.01 \text { and less than } 0\end{array}$} \\
\hline$E M_{1}=1$ Firm years & $\mathrm{n}$ & Mean & Standard Deviation & Maximum & Minimum \\
\hline DTE & 111 & 0.007178073 & 0.022400568 & -0.068117861 & 0.074648544 \\
\hline Total Accruals & 111 & 0.053472629 & 0.147543539 & -0.499576625 & 0.604482928 \\
\hline Abnormal Accruals Jones & 110 & 0.004990158 & 0.144979347 & -0.515932974 & 0.543391 \\
\hline Abnormal Accruals Forward Looking Model & 49 & 0.021133342 & 0.091677721 & -0.124505755 & 0.394041742 \\
\hline$\triangle$ in CFO & 111 & 0.051347661 & 0.185960643 & -0.798577571 & 0.724238072 \\
\hline \multicolumn{6}{|l|}{$E M_{1}=0$ Firm years } \\
\hline DTE & 70 & 0.007103715 & 0.025511495 & -0.042834164 & 0.110967087 \\
\hline Total Accruals & 70 & 0.01847701 & 0.131583798 & -0.326627902 & 0.430159415 \\
\hline Abnormal Accruals Jones & 69 & -0.022442321 & 0.136563547 & -0.382604879 & 0.406582537 \\
\hline Abnormal Accruals Forward Looking Model & 29 & -0.017195708 & 0.059684881 & -0.125776921 & 0.134579228 \\
\hline$\triangle$ in CFO & 70 & -0.032846896 & 0.221559632 & -0.837259674 & 0.769321827 \\
\hline \multicolumn{6}{|c|}{$\begin{array}{l}\text { Panel 02: The Samples of earnings management to avoid a loss in the earnings include zero and slightly positive earnings which is clasified as } E M=1 \text { vs slightly negative } \\
\text { earnings that are clasified as } E M=0 \text {. The firms years of } E M=1 \text { include scaled earning changes }\left[\left(\mathrm{NI}_{\mathrm{t}}\right) / \mathrm{MVE} \mathrm{E}_{(\mathrm{t}-1)}\right] \text { equal to } 0 \text { or less than } 0.02 \text { and the firms years of } E M=0 \text { includes } \\
\text { scaled earnings changes of greater than }-0.02 \text { and less than } 0\end{array}$} \\
\hline $\mathrm{EM}_{2}=1$ Firm years & $\mathrm{n}$ & Mean & Standard Deviation & Maximum & Minimum \\
\hline DTE & 158 & 0.007593607 & 0.022397789 & -0.068117861 & 0.110967087 \\
\hline Total Accruals & 158 & 0.047874059 & 0.143313465 & -0.499576625 & 0.604482928 \\
\hline Abnormal Accruals Jones & 158 & 0.006277109 & 0.141863167 & -0.513607599 & 0.549868797 \\
\hline Abnormal Accruals Forward Looking Model & 77 & 0.001259746 & 0.081608708 & -0.13631191 & 0.358101609 \\
\hline CFO & 158 & 0.131753262 & 0.160686395 & -0.504416642 & 0.734924915 \\
\hline \multicolumn{6}{|l|}{$E M_{2}=0$ Firm years } \\
\hline DTE & 23 & 0.005524285 & 0.027536147 & -0.036393166 & 0.085615809 \\
\hline Total Accruals & 23 & -0.00393818 & 0.12985153 & -0.321300421 & 0.286998395 \\
\hline Abnormal Accruals Jones & 23 & -0.043121011 & 0.134959772 & -0.378200994 & 0.243680679 \\
\hline Abnormal Accruals Forward Looking Model & 10 & -0.009700046 & 0.074688605 & -0.138936579 & 0.09503823 \\
\hline CFO & 23 & -0.026574496 & 0.128783409 & -0.33505572 & 0.129820855 \\
\hline
\end{tabular}

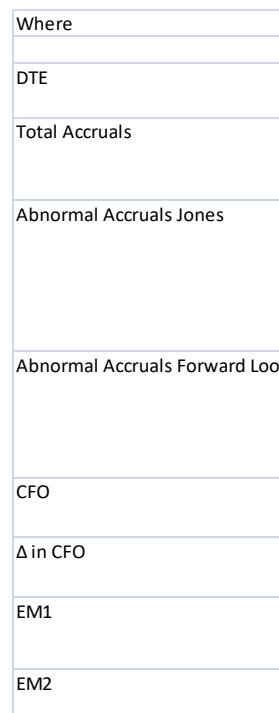

The descripti ve statistics of Table 01

shows the summar statistics for the data. In the Panel 01 of the table 01 the summar

y statistics are shown for the comparison of firms with the zero or slightly positive earnings. The mean deferred tax expense for the firm years $E M=1$ i.e. firm years with zero or slightly positive earnings changes has a mean of 0.0072 or 0.72 percent of the firms beginning of the year's total assets and the median for the same is 0.0049 . The smallest and the largest values are -0.06811 to 0.07464 respectively. The mean for the Total Accruals is 0.0535 or 5.35 percent of the firms beginning of the year's total assets whereas the median for the Total accruals is 0.0491.Largest and the smallest values are 0.6045 and -0.4996 respectively. As we can see that Total Accruals are showing very large figures as compared to the deferred tax expense. Mainly because total accruals are taken before tax and therefore is expected to show a larger figures as compared to the deferred tax expense (Philips et al 2003). Some of the total accruals are negative figures and the reason for the negative figure is attributed to the accruals of depreciation and amortizations. In the $\mathrm{EM}=0$ or the slightly negative earnings changes control sample the mean deferred tax expense is 0.0071 or 0.71 percent and median is 0.0022 . The smallest and the largest values for the deferred tax is -0.0428 and 0.1110 respectively. The total accruals have a mean of 0.0185 and a median of -0.0015 . The smallest and the largest values for the total accruals is -0.3266 and 
0.4302 respectively. Unlike Philips et al (2003) which shows positive abnormal accruals for both the samples, the abnormal accruals for our samples of $E M=1$ is positive whereas for $E M=0$ it is negative.

The two samples have been compared as it is expected that firms that smooth its earnings upward while trying to avoid a reporting of earnings declines the smoothening of earnings should affect the activity. Therefore, the deferred tax expense and the accruals values are expected to be higher in the firms with earnings management activity than that of the control sample of firms i.e. the EM=0. The results in Table 01 shows consistent results with the Philips et al (2003) as the deferred tax expense and total accruals both have significant and larger means and median in the EM=1 sample as compared to the control sample of $\mathrm{EM}=0$.

The Panel 02 of the Table 01 shows the descriptive statistics of the earnings levels of the firm years. The statistics are showing consistent results with the Philips et al (2003) and with deferred tax expense identifying the earnings management activity to avoid a loss. The deferred tax expense mean for the interval of 0 to less than 0.02 is or for the firm years $E M=1$ i.e. firm years with zero or slightly positive earnings levels has a mean of 0.0076 or 0.76 percent of the firms beginning of the year's total assets and the median for the same is 0.0041 . The smallest and the largest values are -0.006811 to 0.11096 respectively. The mean for the Total Accruals is 0.04787 or 4.7 percent of the firms beginning of the year's total assets whereas the median for the Total accruals is 0.04183 . Largest and the smallest values are 0.6045 and -0.4996 respectively. As we can see that Total Accruals are showing very large figures as compared to the deferred tax expense. Mainly because total accruals are taken before tax and therefore is expected to show a larger figures as compared to the deferred tax expense (Philips et al 2003). Some of the total accruals are negative figures and the reason for the negative figure is attributed to the accruals of depreciation and amortizations. In the $\mathrm{EM}=0$ or the slightly negative earnings changes control sample the mean deferred tax expense is 0.0055 or 0.55 percent and median is -0.0006 . The smallest and the largest values for the deferred tax is -0.0364 and 0.0856 respectively. The total accruals have a mean of 0.0039 and a median of -0.0218 . The smallest and the largest values for the total accruals is -0.3213 and 0.2870 respectively. Unlike Philips et al (2003) which shows positive abnormal accruals for both the samples, the abnormal accruals for our samples of $E M=1$ is positive whereas for $E M=0$ it is negative.

There is a positive relationship in the changes in net income and the change in operating cash flows, Dechow (1994) and Philips et al (2003), and a negative correlation between changes cash flows from operations and the total accruals this is consistent with Philips et al (2003) and Sloan (1996). The earnings management variable and the deferred tax expense variables shows positive but small correlation for both the earning changes and earnings levels. Earnings management variable and the total accruals variable also show small positive correlation for both earnings changes and earnings level. Correlations between abnormal accruals and the earnings management variable is also positive but insignificant as it is in in the Total accruals case. As opposed to the Philips et al (2003) and Hanlon (2002) which suggest that multicollinearity between deferred tax expense (DTE) and accrual measures is not an issue but our result of correlations show a positive correlation between deferred tax expense and the all accrual in all three settings.

\subsection{Probit Regression Results}

Unlike Philips et al (2003) results of our research provide little or no evidence of the incremental usefulness of the deferred tax expense. Hence each accrual measure of earnings management to avoid earnings decline and to avoid a loss shows results of inconsistency with the previous research and the results and the setting of Pakistan and Pakistani companies show differing results. We have tabulated results of our research similarly to as it was done by Philips et al (2003). To compare the deferred tax expense usefulness against the other three accrual variables and measures, to compare if there is any usefulness and to compare the results as per pattern given by the Philips et al (2003). 
Table 02 shows results of the deferred tax expense and total accruals for comparison and usefulness test of both the hypotheses. Similarly Table 03 show results of the deferred tax expense and the abnormal accruals calculated through Jones model and Table 03 shows results comparison for the deferred tax and abnormal accruals calculated with Forward Looking Model.

We have tabulated and present the results of the research as per Philips et al (2003) pattern and the Tables 02 shows probit regression results with deferred tax and the total accruals variables. The tables show two settings that is scaled earning changes and the scaled earning levels. As we have not tested the third hypothesis of the Philips et al (2003) paper. The third panel in table is not mentioned in all three tables in comparison as it was mentioned in the Philips et al (2003) paper. The reason for which is already mentioned above. In the tables the scaled earning changes shows the results of the probit model for avoiding an earnings declines and the scaled earnings level shows results of probit model to avoid a loss.

\begin{tabular}{|c|c|c|c|c|}
\hline \multicolumn{5}{|l|}{ Table 02 } \\
\hline \multicolumn{5}{|c|}{ Probit Regression Results for Comparison of Deferred Tax Expense to Total Accruals } \\
\hline & \multicolumn{2}{|c|}{ Scaled Earning Changes } & \multicolumn{2}{|c|}{ Scaled Earnings } \\
\hline & $\mathrm{n}=\mathbf{1 8 1}$ & P value & $\mathrm{n}=\mathbf{1 8 1}$ & P value \\
\hline Intercept & 0.029585 & 0.7982 & 0.397026 & 0.0223 \\
\hline DTE & 3.980479 & 0.3801 & -1.619721 & 0.8168 \\
\hline TA & 4.708421 & $<0.0000$ & 12.19225 & $<0.0000$ \\
\hline$\triangle \mathrm{CFO} \&$ CFO & 3.719364 & $<0.0000$ & 13.69673 & $<0.0000$ \\
\hline $\begin{array}{l}\text { No. of Correct } \\
\text { Predictions }\end{array}$ & $73.48 \%$ & & $87.85 \%$ & \\
\hline Log Likely Hood & -105.5132 & & -37.19729 & \\
\hline \multicolumn{5}{|l|}{ Where } \\
\hline DTE & \multirow{2}{*}{\multicolumn{4}{|c|}{$\begin{array}{l}\text { Deferred tax expense scaled by the total assets of previous year i.e t- } 1 \\
\text { Total accruals are computed by subtracting cash flows from operations } \\
\text { from earning before extra-ordinary items and then it is scaled by the } \\
\text { total assets of the previous year's i.e t- } 1\end{array}$}} \\
\hline Total Accruals & & & & \\
\hline $\mathrm{CFO}$ & \multicolumn{4}{|c|}{ Cash flow from year $\mathrm{t}$ scaled by the total assets of the year $\mathrm{t}-1$} \\
\hline$\Delta$ in $\mathrm{CFO}$ & \multicolumn{4}{|c|}{$\begin{array}{l}\text { Is Change in Cash flow from year t to } t-1 \text { scaled by the total assets of the } \\
\text { year } t-1\end{array}$} \\
\hline
\end{tabular}

In Table 02 we can see that the results are in contrary to the previous research of Philips et al (2003) and show the total accrual (TA) have a coefficient of 4.70821 as compared to the deferred tax expense (DTE) which is 3.980479 with $P$ value of 0.3801 which show that Total accruals is a better measure and measuring the earnings management through accruals is better. Although both variables has a positive and higher coefficient and are also significant i.e. $\mathrm{P}$ value for the deferred tax is 0.3801 whereas it is $<0.0001$ for total accruals. As expected the Changes in cash flows are positive with 3.719364 and $\mathrm{P}$ value of $<0.0001$.

Similarly the results for the scaled earnings changes in the table 02 shows a negative coefficient for the deferred tax expense by -1.61972 with $\mathrm{P}$ value of 0.8168 as compared to the total accruals coefficient of 12.19225 with $\mathrm{P}$ value of $<0.0001$. With these results we can see that in both the above settings the incremental usefulness of the deferred tax hypotheses is rejected. As the deferred tax expense has insignificant $P$ value in both the above setting,hence, we can say that total accruals are incrementally useful measure as opposed to deferred tax expense in identifying the earnings management to avoid an 
earnings decline and to avoid a loss.

\begin{tabular}{|c|c|c|c|c|}
\hline \multicolumn{5}{|c|}{ Table 03} \\
\hline \multicolumn{5}{|c|}{$\begin{array}{c}\text { Probit Regression Results for Comparison of Deferred Tax Expense to Modified Jones } \\
\text { Abnormal Accruals }\end{array}$} \\
\hline & \multicolumn{2}{|c|}{ Scaled Earning Changes } & \multicolumn{2}{|c|}{ Scaled Earnings } \\
\hline & $n=179$ & P value & $n=181$ & P value \\
\hline Intercept & 0.250515 & 0.0180 & 0.881349 & $<0.0000$ \\
\hline DTE & 3.656635 & 0.4231 & -3.333642 & 0.6234 \\
\hline MJ Acc & 4.422208 & $<0.0000$ & 11.60549 & $<0.0000$ \\
\hline$\triangle \mathrm{CFO} \& \mathrm{CFO}$ & 3.673607 & $<0.0000$ & 13.22449 & $<0.0000$ \\
\hline $\begin{array}{l}\text { No. of Correct } \\
\text { Predictions }\end{array}$ & $72.38 \%$ & & $87.85 \%$ & \\
\hline Log Likely Hood & -105.0502 & & -38.01346 & \\
\hline
\end{tabular}

Where

DTE

Abnormal

Accruals Jones
Deferred tax expense scaled by the total assets of previous year i.e t-1 Modified Jones model is used following Dechow et al (1995) by deducting normal accruals from the Total Accruals. The Normal Accruals are calculated using Jones model as TAccit $=\alpha+\beta 1(\Delta$ Salesit $\Delta$ ARit $)+\beta 2$ PPEit $+\dot{\varepsilon}$. The chance in sales is calculated by subtracting sales of previous year(t-1) from sales of the current year (t) similarly the change in the accounts receivables is arived at by deducted previous years receivables $(t-1)$ from current years $(t)$. PPE is gross property plant and equipment. All the variables are scaled by the total assets of previous year.

$\mathrm{CFO} \quad$ Cash flow from year $\mathrm{t}$ scaled by the total assets of the year $\mathrm{t}-1$

$\Delta$ in CFO Is Change in Cash flow from year $\mathrm{t}$ to $\mathrm{t}-1$ scaled by the total assets of the year $\mathrm{t}-1$

In Table 03 also the results are similar to Table 02 and therefore is in contrary to the previous research of Philips et al (2003) and show the abnormal accruals (MJ Acc) have a coefficient of 4.42221 with $\mathrm{P}$ value of $<0.0001$ as compared to the deferred tax expense (DTE) coefficient of -3.3336 with $P$ value of 0.6234 which again shows that abnormal accruals calculated through Jones Models is a better measure and measuring the earnings management through accruals is better as Deferred tax expense is also insignificant. As expected the changes in cash flows are positive with 3.6736 and has a $\mathrm{P}$ value of $<0.0001$.

Similarly the results for the scaled earnings changes in the table 03 shows a negative coefficient for the deferred tax expense by -3.3364 with $\mathrm{P}$ value of 0.6234 as compared to the total accruals coefficient of 11.60549 with $\mathrm{P}$ value of $<0.0001$. Again as in both the settings the deferred tax expense variable is insignificant. Thereforethe total accruals are incrementally useful measure as opposed to deferred tax expense in identifying the earnings management to avoid an earnings decline and to avoid a loss.

Table 04

Probit Regression Results for Comparison of Deferred Tax Expense to Forward Looking Model Abnormal Accruals 


\begin{tabular}{|l|c|c|c|c|}
\hline & $\mathbf{n = 7 8}$ & $\mathbf{P}$ value & $\mathbf{n = 8 7}$ & P value \\
\hline Intercept & 0.359902 & 0.0225 & 1.147150 & $<0.0000$ \\
\hline DTE & -0.683721 & 0.9314 & -3.143668 & 0.7324 \\
\hline FL Acc & 8.062171 & 0.0045 & 16.48475 & 0.0129 \\
\hline$\Delta$ CFO \& CFO & 2.48318 & 0.0143 & 13.36650 & 0.0010 \\
\hline $\begin{array}{l}\text { No. of Correct } \\
\text { Predictions }\end{array}$ & $71.59 \%$ & & $94.48 \%$ & \\
\hline Log LikelyHood & -45.32748 & & -20.44508 & \\
\hline
\end{tabular}

Where

DTE

Total Accruals

Deferred tax expense scaled by the total assets of previous year i.e t-1

Total accruals are computed by subtracting cash flows from operations from earning before extra-ordinary items and then it is scaled by the total assets of the previous year's i.e t-1

FL Acc It is computed by deducting normal accruals computed by forward looking Jones model (Dechow et al. 2002). The normal accruals with the forward looking models are computed as TA ccit $=\alpha+\beta 1(\Delta$ Salesit $-(1-\mathrm{k}) \Delta$ ARit $)+\beta 2$ PPEit $+\beta 3$ TAccit$1+\beta 4$ Salesit $+1+\dot{\varepsilon}$. In this equation the $\mathrm{k}$ is slope coefficient of change in accounts receivable on change in sales and is result of regression. Total accruals are scaled by Total Assets(t-2) i.e. total assets of 2 nd last year. Salesit is change in sales from to $\mathrm{t}+1$ divided by $\mathrm{t}$.

CFO

$\triangle$ in $\mathrm{CFO}$

Cash flow from year $t$ scaled by the total assets of the year $t-1$

Is Change in Cash flow from year $\mathrm{t}$ to $\mathrm{t}-1$ scaled by the total assets of the year $\mathrm{t}-1$

The results of the table 04 shows that deferred tax expense has a coefficient of -0.683721 and $\mathrm{P}$ value of 0.9314 as compared to the accruals calculated through Forward Looking model which has the coefficient of 8.06217 with $\mathrm{P}$ value of 0.0045 for the earnings changes to avoid earnings decline and for . Similarly in the scaled earnings i.e. to avoid a loss sample the deferred tax expense (DTE) has a coefficient of -314367 with $\mathrm{P}$ value of 0.7324 as compared to the abnormal accruals calculated through the forward looking model which has coefficient of 16.48475 with $\mathrm{P}$ value of 0.0129 . Hence in all the above settings it can be seen that Deferred tax expense in not incrementally useful beyond total accruals. Number of correct predictions

As the R square measure of OLS is not applicable to binary dependent variables in probit regression model a number of correct predictions have been used. The number of correct predictions for each calculation is given above in table 02,03 and 04 which shows that all the three tables shows the number of correct predictions over $71 \%$ which is significant.

\section{Limitations}

The data availability has been one of the biggest constraints for our study as the main variable under the study is deferred tax expense and that component was missing in the State Bank of Pakistan Publication Balance Sheet Analyses of listed companies on KSE. Therefore, this study resorted to financial reports of individual companies and as it was not possible to go beyond five years we kept our study limited to span of five years.

The results may bring some difference if the study is spanned over the ten years period of firm and with the inclusion of more firms.

No sensitivity tests were conducted in this study. Company performance can provide some evidence about the usefulness of the deferred tax expense if in the probit regression three more control variables are incorporated which are assets growth, growth, and the average return on assets. But as our study it is 
not useful we cannot go on and see the affects of these variables because the initial tests show insignificant results.

In this study while we were investigating the incremental usefulness of the deferred tax expense with the other accrual measures in detecting the earnings management to avoid loss must be further investigated to find out if the change in cash flow against the level of cash flows is taken to measure the performance of the company.

\section{Conclusion}

The managers have generally more discretion in Accounting Standards (i.e. IAS or GAAP) than in tax rules and thus would allow managers to manage earnings. Although there are other methods available to detect the earnings management i.e accrual models but we have tested the incremental usefulness of the deferred tax expense in detecting earnings management. It is expected that the mangers would manage the earnings upward while remaining within the Accounting Standards and would do so by not increasing the current income taxes payable. Hence that earnings management behavior will ultimately result in temporary book tax differences and would result in higher deferred tax expense. The evidence of this study has been built on the basis of studies of Burgstahler and Dichev (1997), Degeorge et al. (1999) Mills and Newberry (2001) and on the evidence of a significant measurement error in accrual measure in Guay et al. (1996) these studies are mention in Philips et al. (2003). The incremental usefulness of the deferred tax expense is evaluated to detect the earnings management for two earnings targets i.e to last year's earnings and zero earnings.

The results are inconsistent with the previous research of Philips et al. (2003) in which it was concluded that the deferred tax expense is incrementally useful in detecting the earnings management. According to the results of our study the accrual measures of all three models are significant,and therefore are useful in the detection of earnings management whereas the deferred tax expense is consistently insignificant and is not incrementally useful beyond the other accrual models of total accruals, modified Jones mode of abnormal accruals, and forward looking abnormal accruals in both the cases of detecting the earnings management i.e for earning decline and avoiding a loss.

Hence based on our study we can concluded that in Pakistan the deferred tax expense is not incrementally useful along with the other accrual measure of total accruals, modified Jones abnormal accruals and Forward looking mode of abnormal accruals. Hence as the results differ for the Pakistani Scenario it may also differ for the sub continent firm or more over for the Asian firms. As contrary to Philips et al. (2003), the deferred tax expense cannot supplement accruals measures in detecting earnings management to avoid and earnings decline and to avoid a loss as the results for the both the cases have insignificant results for the Pakistani firms. However, the study may yieldslightly different results if the span of study is expanded to ten years and by including more number of firms.

\section{References}

Beneish, M. D. (1998). 'Discussion of "Are accruals during initial public offeringsopportunistic?"'. Review of Accounting Studies, 3: 209-221.

Beneish, M. D, (2001) "Earning management: A perspective” Managerial Finance; Vol: 27, Number 12 Pg. 3

Burgstahler, D., W. Elliott, and M. Hanlon. (2003). "How firms avoid losses: Evidence of use of the net deferred tax asset account", Working paper, University of Washington.

Ben-HsienBao And Da-HsienBao (2004), "Income Smoothing, Earnings Quality and Firm Valuation" 
Journal of Business Finance \&Accounting, 31(9) \& (10), November/December 2004, 0306-686X Christian Leuz et al(2003) "Earnings management and investor protection: an international comparison" Journal of Financial Economics

Chung, R., Ho, S. and Kim, J. (2004) 'Ownership structure and the pricing of discretionary accruals in Japan', Journal of International Accounting, Auditing \& Taxation, 13, pp. 1-20.

Dechow, P., Sloan, R. and Sweeney, A. (1995). 'Detecting earnings management'.The Accounting Review, 70: 193-225.

Dhaliwal, Dan S, Gleason C.A, Mills, L.F (2004) "Last-Chance Earnings Management: Using theTax Expense to Meet Analysts' Forecasts"Contemporary Accounting ResearchVol. 21 No. 2 (Summer 2004) pp. 431-59 (C) CAAA

Fan, J., P.H. and Won, T.J. (2002). Corporate ownership structure and the informativeness accounting earnings in East Asia, Journal of Accounting and Economics, 33:401-425.

Frank, M.M. and Rego, S.O. (2005). Do managers use the valuation allowance account to manage earnings around certain earnings targets? Working Paper, University of Virginia.

Guay, W.R., Kothari, S. P. and Watts, R. (1996).'A market-based evaluation of discretionary accrual models'.Journal of Accounting Research, 34: 83-105.

Healy, P. (1985). 'The effect of bonus schemes on accounting decisions'. Journal of Accounting and Economics, 7: 85-107

Holland, Kevin M. and Jackson, Richard H.G. (2002), Earnings Management and Deferred Tax. Available at SSRN: http://ssrn.com/abstract=327220 or doi:10.2139/ssrn.327220

Hunt, A., Moyer, S. and Shevlin, T. (1995) 'Earnings smoothing and equity value', Working paper, University of Washington.

IlanitGavious, (2007) "Market Reaction to Earnings Management: The Incremental Contribution of Analysts" International Research Journal of Finance and Economics ISSN 1450-2887 Issue 8 EuroJournals Publishing, Inc.

Anne L Beatty; Bin Ke; Kathy R Petroni (2002) "Earnings management to avoid earnings declines across pubicily and privately" The Accounting Review; 77, 3; ABI/INFORM Global pg. 547

Jimmy Lee, May (2007) “Earnings Management to Just Meet Analysts' Forecast”Kellogg Graduate School of Management Northwestern University

Junaid Ashraf, Waqar I. Ghani(2005) “Accounting development in Pakistan" The International Journal of Accounting 40 (2005) 175 - 201

M.F McNichols (2000) Paper Research Design Issues in earnings management studies in Journal of Accounting and Public Policy 19 (2000) 317-318

OhadKadan\& Jun Yang, (2004)" Executive Stock Options and Earnings Management: A Theoretical and Empirical Analysis"

Patricia M. Dechow and Douglas J. Skinner, (2000) "Earnings Management: Reconciling the Views of Accounting Academics, Practitioners, and Regulators" University of Michigan Business School 701 Tappan Street Ann Arbor, MI 48109-1234

R. Chung et al. (2002) "Institutional monitoring and opportunistic earnings management" Journal of Corporate Finance 308 P29-48

Robinson-Backmon and Finney (1999)Research on Accounting Ethics 1999, 5: 77-93

Schipper, K., (1989), Commentary on earnings management,Accounting Horizons, 3.91-102.

Shai Levi, (2007)"Voluntary disclosure of accruals in earnings press releases and the pricing of accruals" Published online: 31 October 2007 Springer Science Business Media, LLC

Subramanyam, K. (1996) 'The pricing of discretionary accruals', Journal of Accounting and Economics, 22, pp. 249-281.

Soon Suk Yoon (2005) “A Comparison of Earnings Management Between KSE Firms and KOSDAQ Firms" Journal of Business Finance \& Accounting, 32(7) \& (8), September/October 2005, 0306-

Teoh, S. H., Wong, T. J. and Rao, G. R. (1998). 'Are accruals during initial public offerings 
opportunistic?'.Review of Accounting Studies, 3: 175-208.

Young, S. (1999). 'Systematic measurement error in the estimation of discretionary accruals: an evaluation of alternative modeling procedures'. Journal of Business, 68 